\title{
CHARACTERISTICS OF WORD-FORMATION ROWS WITH THE SUFFIX -MENT
}

\author{
Olena Dotsenko \\ Postgraduate Student at the Department of Translation Studies \\ and Linguistic Training of Foreigners, Oles Honchar Dnipro National University, Ukraine \\ e-mail: edots@ukr.net,orcid.org/0000-0002-7549-4290
}

\section{Summary}

The article is devoted to the study and analysis of word-formation rows with the suffix -ment. The attempt to identify the patterns and principles of creating English word-formation rows was made. Word-formation rows were studied in terms of their complexity, word-formation ways of derivatives, and the lexical and grammatical nature of the generating words. Not only the verbal, nominal, and adverbial rows, but also the confixed verbal, nominal and adverbial ones were analyzed. Besides, the examples of complex name rows consisting of words formed by combining two stems are presented in this article. The structure of each row was examined deeply with the help of the relator speech of the applicative generative model (AGM), which is a universal tool for studying the structure of word-formation rows in any language. Completing the comparative analysis of $\mathrm{R}=$ structures and $\mathrm{L}=$ structures helped not only realize how $\mathrm{R}=$ structures are resembled in natural language, but also determine the complexity of word-formation rows. It should be noted that word-formation rows with the suffix -ment are described in the article in terms of their homogeneity and heterogeneity. The categories of derivatives conjugated with the word-formation suffix -ment are systematized.

Keywords: a macro row, $\mathrm{L}=$ structure, $\mathrm{R}=$ structure, the complexity of rows, homogeneous $\mathrm{R}=$ structure, heterogeneous $\mathrm{R}=$ structure.

DOI: https://doi.org/10.23856/4403

\section{Introduction}

Despite the significant contribution of both domestic and foreign scientists to the study of word-formation of the Germanic languages, it is necessary to substantiate and analyze English word-formation rows nowadays. The relevance and novelty of the article is the study of word-formation rows in the English language. The object of the study is English words with the suffix -ment. The purpose of the article is to describe word-formation rows. Fulfilling several tasks will assist in achieving the above-mentioned purpose. These tasks are: 1) analysis of morpheme stems according to the part of speech they belong to; 2) classification of rows according to the category of derivative; 3 ) comparison of word-forming $\mathrm{R}=$ series with $\mathrm{L}=$ words row; 4) identification the complexity of word-formation rows with the suffix -ment.

The methodology of the research includes both theoretical methods such as general scientific and construction methods and empirical ones like descriptive and comparative analysis methods which can lead to carrying out the mentioned tasks. The scientific papers of such linguists as P. A. Soboleva and Yu. A. Shepel will comprise the theoretical basis of the article.

The article deals with the rows consisting of morpheme stems belonging to one part of speech i.e. the verb, the noun or the adjective (with one exception of few examples of morpheme stems belonging to several parts of speech). Rows with polysemantic stems will be considered in our further papers. 


\section{Definition of the main theoretical concepts}

P. A. Soboleva stated that classes of words entering into word-formation relations can represent word-formation rows and classes of word-formation rows (Soboleva, 1980). The scientist supposed the word-formation $\mathrm{L}=$ rows to be a finite set of natural language words ( $\mathrm{L}=$ words) that could be both similar and different, but with the same word-formation suffix.

The article is based on the works by Yu.A. Shepel who defines a word-formation row as "a finite set of words with the identical affix at the last derivational step" (Shepel, 2006: 14; Shepel 2005). L=structure is a set of word classes of a real (natural) language united by a common word-formation means, e.g. words with the suffix -ment: content, argument, lavement, treatment, assessment, averment, interment, etc.

$\mathrm{R}=$ structure $^{1}$ is understood as a set of $\mathrm{R}=$ words correlated with $\mathrm{L}=$ structures. For example, $\mathrm{L}=$ structures of verbal nouns with the suffix -ment correspond to such a set of $\mathrm{R}=$ words as $R_{2} R_{1} O, R_{2} R_{1} R_{1} O, R_{2} R_{2} R_{1} O, R_{2} R_{2} R_{2} R_{1} O, R_{2} R_{1} R_{2} R_{1} O$. L = structures of the nominal rows with the suffix -ment correspond to such a set of R=words as $\boldsymbol{R}_{2} \boldsymbol{R}_{2} \boldsymbol{O}, \boldsymbol{R}_{2} \boldsymbol{R}_{1} \boldsymbol{R}_{2} \boldsymbol{O}, \boldsymbol{R}_{2} \boldsymbol{R}_{2} \boldsymbol{R}_{2} \boldsymbol{O}$. The set of $\mathrm{R}=$ words such as $\boldsymbol{R}_{2} \boldsymbol{R}_{3} \boldsymbol{O}$ corresponds to adverbial structures of L=rows with the suffix -ment.

Word-formation rows will be considered according to the principle of their homogeneity and heterogeneity. Yu. A. Shepel states that homogeneous $\mathrm{R}=$ structures have the same meaning of $i$ at the $n$ (penalt) step. If the meaning of $i$ at the penult derivational step does not coincide, then such structures are called heterogeneous. Consequently, $L=$ structures can also acquire the properties of homogeneity and heterogeneity (Shepel, 2006; Shepel, 2009).

P. A. Soboleva introduces the concept of the degree of row complexity measured by the number of word-formation structures that can be an invariant of a row (Soboleva, 1980). In her opinion, there is an inverse relationship between the complexity of $\mathrm{R}=$ rows and the number of corresponding word-formation $\mathrm{L}=$ rows.

Let's consider and analyze word-formation rows according to the above mentioned characteristics, i.e. the correspondence of $\mathrm{R}=$ rows to $\mathrm{L}=$ rows and the degree of complexity.

\section{Verbal word-formation rows}

The verbal rows represent the most numerous group of word-formation rows with the suffix -ment. These are rows with a verb as a morpheme stem. $\mathrm{R}=$ structures of such rows are considered and arranged below. As a result, we found combinations of numbers corresponding to verbal word-formation $\mathrm{R}=$ structures and they can be shown like 21, 211, 221, 2221, 2121. Let's write these sequences as $\mathrm{R}=$ words and put down $\mathrm{L}=$ words corresponding to these sequences:

$\boldsymbol{R}_{2} \boldsymbol{R}_{1} \boldsymbol{O}$ adornment, pavement, commitment, obligement, commencement, secondment, argument, lavement, attachment, detachment, retardment, amerciament, management, ejectment, recruitment, chastisement, treatment, deplorement, harassment, development, minishment, revetment, publishment

$\boldsymbol{R}_{2} \boldsymbol{R}_{1} \boldsymbol{R}_{1} \boldsymbol{O}$ anointment, erasement, amendment, entwinement, procurement, immurement, attemperment, incitement, intendment, avouchment, incensement, derivement

$\boldsymbol{R}_{2} \boldsymbol{R}_{2} \boldsymbol{R}_{1} \boldsymbol{O}$ midargument, maldevelopment, overallotment, overcommitment, overattachment, nonagreement, noninvestment, pretreatment, micromanagement, microenvironment

The language of the applicative generative model (APM) offered by S. K. Shaumyan and P. A. Soboleva was used for analyzing the structure of words and creating word-formation rows. This language is described in details in the textbook by S. K. Shaumyan, P.A. Soboleva "The fundamentals of the generative grammar of the Russian language / Introduction to genotypic structures". Moscow. 1968. 372 p. 
$\boldsymbol{R}_{2} \boldsymbol{R}_{1} \boldsymbol{R}_{\boldsymbol{1}} \boldsymbol{O}\left(\boldsymbol{R}_{2} \boldsymbol{R}_{2} \boldsymbol{R}_{1} \boldsymbol{O}\right)^{2}$ forebodement, posttreatment, diminishment, outsettlement, misgovernment, misalignment, retreatment, reinvestment, restatement, readornment, reassessment, replenishment

$\boldsymbol{R}_{2} \boldsymbol{R}_{2} \boldsymbol{R}_{2} \boldsymbol{R}_{1} \boldsymbol{O}\left(\boldsymbol{R}_{2} \boldsymbol{R}_{1} \boldsymbol{R}_{2} \boldsymbol{R}_{1} \boldsymbol{O}\right)^{3}$ repolishment, assortment, adjudgement, admeasurement

There is an example of a heterogeneous row among the above mentioned words, e.g. anointment, midargument, forebodement, repolishment. The penultimate relator is both $\mathrm{R}_{1}$ and $\mathrm{R}_{2}$ in this row.

Referring to the monograph by Yu. A. Shepel, it is possible to consider an arranged row of $\mathrm{R}=$ words to be a macro row of verbal word-formations by the metalanguage level of the applicative generative model (Shepel, 2006; Shepel 1989). Here is an example of a macro row consisting of the above mentioned words: pavement, erasement, midargument, forebodement, repolishment $\left(\boldsymbol{R}_{2} \boldsymbol{R}_{1} \boldsymbol{O}, \boldsymbol{R}_{2} \boldsymbol{R}_{1} \boldsymbol{R}_{1} \boldsymbol{O}, \boldsymbol{R}_{2} \boldsymbol{R}_{2} \boldsymbol{R}_{1} \boldsymbol{O}, \boldsymbol{R}_{2} \boldsymbol{R}_{1} \boldsymbol{R}_{1} \boldsymbol{O}\left(\boldsymbol{R}_{2} \boldsymbol{R}_{2} \boldsymbol{R}_{1} \boldsymbol{O}\right), \boldsymbol{R}_{2} \boldsymbol{R}_{2} \boldsymbol{R}_{2} \boldsymbol{R}_{1} \boldsymbol{O}\left(\boldsymbol{R}_{2} \boldsymbol{R}_{1} \boldsymbol{R}_{2} \boldsymbol{R}_{1} \boldsymbol{O}\right)\right)$.

Table 3.1

Verbal word-formation $R=$ and $L=$ rows

\begin{tabular}{|c|c|}
\hline $\begin{array}{c}\text { Word-formation } \\
\text { R=row }\end{array}$ & $\begin{array}{c}\text { Word-formation } \\
\text { L=row }\end{array}$ \\
\hline $\mathrm{R}_{2} \mathrm{R}_{1} \mathrm{O}$ & $\begin{array}{l}\text { adornment, pavement, commitment, obligement, commencement, } \\
\text { secondment, argument, lavement, attachment, detachment, retard- } \\
\text { ment, amerciament, management, ejectment, recruitment, chastise- } \\
\text { ment, treatment, deplorement, harassment, development, minishment, } \\
\text { revetment, publishment }\end{array}$ \\
\hline $\mathrm{R}_{2} \mathrm{R}_{2} \mathrm{R}_{1} \mathrm{O}$ & $\begin{array}{l}\text { midargument, maldevelopment, overallotment, overcommitment, } \\
\text { overattachment, nonagreement, noninvestment, pretreatment, micro- } \\
\text { management, microenvironment }\end{array}$ \\
\hline $\mathrm{R}_{2} \mathrm{R}_{1} \mathrm{R}_{1} \mathrm{O}$ & $\begin{array}{l}\text { anointment, erasement, amendment, entwinement, procurement, } \\
\text { immurement, attemperment, incitement, intendment, avouchment, } \\
\text { incensement, derivement }\end{array}$ \\
\hline $\mathrm{R}_{2} \mathrm{R}_{1} \mathrm{R}_{1} \mathrm{O}\left(\mathrm{R}_{2} \mathrm{R}_{2} \mathrm{R}_{1} \mathrm{O}\right)$ & $\begin{array}{l}\text { forebodement, posttreatment, diminishment, outsettlement, mis- } \\
\text { government, misalignment, retreatment, reinvestment, restatement, } \\
\text { readornment, reassessment, replenishment }\end{array}$ \\
\hline $\mathrm{R}_{2} \mathrm{R}_{2} \mathrm{R}_{2} \mathrm{R}_{1} \mathrm{O}\left(\mathrm{R}_{2} \mathrm{R}_{1} \mathrm{R}_{2} \mathrm{R}_{1} \mathrm{O}\right)$ & adjudgement, admeasurement, repolishment, assortment \\
\hline
\end{tabular}

Table 3.1 proves that the complexity of the row is 3 .

Thus, the verbal rows are heterogeneous and complex.

\section{Nominal word-formation rows}

A nominal word-formation row is a row with a nominal morpheme stem. Let's analyze and arrange $\mathrm{R}=$ structures of such rows. There are combinations of numbers corresponding to the word-formation $\mathrm{R}=$ structures which look like as follows 22, 212. Let's write these sequences as $\mathrm{R}=$ words and represent the words of this sequence corresponding to $\mathrm{L}=$ words:

$\boldsymbol{R}_{2} \boldsymbol{R}_{2} \boldsymbol{O}$ indument, muniment, rabblement, ledgement, scriptment, justicement, devilment, feoffment, enrockment

2 There can be both a verb and a noun at the second derivational step in these words.

3 These words comprise the morpheme stem belonging to both a verb and a noun. 
It is necessary to pay attention to the word enrockment in this $\mathrm{R}=$ structure. The fact is that both the prefix pre- and the suffix -ment are added to its morpheme stem rock at the last derivational step.

$\boldsymbol{R}_{2} \boldsymbol{R}_{1} \boldsymbol{R}_{2} \boldsymbol{O}$ embayment, empowerment, disillusionment, dismemberment, discouragement, disbarment, disbursement, enserfment, entrancement, enticement, encystment, accoutrement, disparagement, debouchment.

Nominal word-formation rows are heterogeneous. There is an example of such row muniment-embayment with different relators $\mathrm{R}_{2}$ and $\mathrm{R}_{1}$ presented at the penultimate derivation step.

Table 4.1

Nominal word-formation $R=$ and $L=$ rows

\begin{tabular}{|l|l|}
\hline \multicolumn{1}{|c|}{$\begin{array}{c}\text { Word-formation } \\
\mathbf{R}=\text { row }\end{array}$} & \multicolumn{1}{c|}{$\begin{array}{c}\text { Word-formation } \\
\text { L=row }\end{array}$} \\
\hline $\mathrm{R}_{2} \mathrm{R}_{2} \mathrm{O}$ & $\begin{array}{l}\text { indument, muniment, rabblement, ledgement, scriptment, justicement, } \\
\text { devilment, feoffment }\end{array}$ \\
\hline $\mathrm{R}_{2} \mathrm{R}_{1} \mathrm{R}_{2} \mathrm{O}$ & $\begin{array}{l}\text { embayment, empowerment, disillusionment, dismemberment, discourage- } \\
\text { ment, disbarment, disbursement, enserfment, entrancement, enticement, } \\
\text { encystment, disparagement, debouchment }\end{array}$ \\
\hline
\end{tabular}

Table 4.1 shows that that the row complexity is 2 . So, the nominal rows will be considered to be simple and heterogeneous in structure.

It is worth paying attention to another structure different from the above mentioned one. It is the structure with bound root that can be shown as $\boldsymbol{R}_{2} \boldsymbol{O}+$ noun with a bound root. With the help of this structure, it is possible to form a row of complex names e.g. photopigment, radioelement, pseudomoment, depigment, orpigment. Analyzing structures with bound roots is not the purpose of the article, so such structures won't be described in detail.

\section{Adverbial word-formation rows}

The adverbial word-formation row is a row with adverbial morpheme stem. Let's consider adverbial word-formation rows with the suffix -ment and arrange $\mathrm{R}=$ structures of these rows. There are combinations of numbers corresponding to adverbial word-formation structures which look like as follows 23,213 . Let's write these sequences as $\mathrm{R}=$ words and represent the words of this sequence corresponding to $\mathrm{L}=$ words:

$\boldsymbol{R}_{2} \boldsymbol{R}_{3} \boldsymbol{O}$ securement, jolliment, supplement, merriment, sacrament

$\boldsymbol{R}_{2} \boldsymbol{R}_{I} \boldsymbol{R}_{3} \boldsymbol{O}$ annulment, ascertainment, estrangement, disablement, embrittlement, enfeeblement, ennoblement, enlargement, refreshment, revilement, refinement

Here is an example of an adverbial word-formation row which has a heterogeneous structure, e.g. securement - annulment, with different relators $\mathrm{R}_{3}$ and $\mathrm{R}_{1}$ at the penultimate derivational step.

Table 5.1

Adverbial word-formation $\mathrm{R}=$ and $\mathrm{L}=$ rows

\begin{tabular}{|l|l|}
\hline \multicolumn{1}{|c|}{$\begin{array}{c}\text { Word-formation } \\
\mathbf{R}=\text { row }\end{array}$} & \multicolumn{1}{c|}{$\begin{array}{c}\text { Word-formation } \\
\mathbf{L}=\text { row }\end{array}$} \\
\hline $\mathrm{R}_{2} \mathrm{R}_{3} \mathrm{O}$ & securement, jolliment, supplement, merriment, sacrament \\
\hline $\mathrm{R}_{2} \mathrm{R}_{1} \mathrm{R}_{3} \mathrm{O}$ & $\begin{array}{l}\text { annulment, ascertainment, estrangement, disablement, embrittlement, enfee- } \\
\text { blement, ennoblement, enlargement, refreshment, revilement, refinement }\end{array}$ \\
\hline
\end{tabular}


Table 5.1 displays that the row complexity is 2 .

Thus, adverbial rows will be simple with heterogeneous structure.

\section{Typological characteristics of word-formation rows}

The structural organization of word-formation rows implies the partitioning principle, then these elements are combined into the whole structure.

Yu. A. Shepel states that the type of word-formation rows is determined, on the one hand, by the type of derivatives according to the word-formation method at the last step of derivation (Shepel, 2006). It means that rows can be prefixed, suffixed or confixed. Besides, the type of rows depends on the lexical and grammatical nature of the derivational elements of rows (verbal, nominal, adverbial) or morpheme stems (verbal, nominal, adverbial).

Table 6.1

Typological characteristics of word-formation structures

of the confixed macro row of nouns (L)

\begin{tabular}{|c|c|c|c|c|}
\hline $\begin{array}{c}\text { Derivative } \\
\text { category }\end{array}$ & $R=$ word & $\begin{array}{l}\text { Step } \\
\text { No. }\end{array}$ & $\begin{array}{l}\text { Confixed derived words } \\
\text { (of natural language) }\end{array}$ & $\begin{array}{c}\text { Generative word (words } \\
\text { of natural language) }\end{array}$ \\
\hline \multirow[t]{3}{*}{$\begin{array}{l}\text { Verbal nouns } \\
\mathrm{R}_{2} \mathrm{R}_{1} \mathrm{X}\end{array}$} & $\mathrm{R}_{2} \mathrm{R}_{2} \mathrm{R}_{1} \mathrm{O}$ & II & $\begin{array}{l}\text { overinvestment } \\
\text { overrecruitment } \\
\text { overallotment } \\
\text { overattachment } \\
\text { overcommitment } \\
\text { malinvestment } \\
\text { maldevelopment } \\
\text { maltreatment } \\
\text { microenvironment } \\
\text { micromanagement } \\
\end{array}$ & $\begin{array}{l}\text { invest } \\
\text { recruit } \\
\text { allot } \\
\text { attach } \\
\text { commit } \\
\text { invest } \\
\text { develop } \\
\text { treat } \\
\text { environ } \\
\text { manage } \\
\end{array}$ \\
\hline & $\begin{array}{l}\mathrm{R}_{2} \mathrm{R}_{2} \mathrm{R}_{1} \mathrm{O} \\
\left(\mathrm{R}_{2} \mathrm{R}_{1} \mathrm{R}_{1} \mathrm{O}\right) \\
\end{array}$ & II & $\begin{array}{l}\text { misgovernment } \\
\text { misalignment }\end{array}$ & $\begin{array}{l}\text { govern } \\
\text { align }\end{array}$ \\
\hline & $\begin{array}{l}\mathrm{R}_{2} \mathrm{R}_{2} \mathrm{R}_{2} \mathrm{R}_{1} \mathrm{O} \\
\left(\mathrm{R}_{2} \mathrm{R}_{1} \mathrm{R}_{2} \mathrm{R}_{1} \mathrm{O}\right)\end{array}$ & III & $\begin{array}{l}\text { adjudgement } \\
\text { admeasurement }\end{array}$ & $\begin{array}{l}\text { judge } \\
\text { measure }\end{array}$ \\
\hline $\begin{array}{l}\text { Nominal nouns } \\
\mathrm{R}_{2} \mathrm{R}_{2} \mathrm{X}\end{array}$ & $\mathrm{R}_{2} \mathrm{R}_{1} \mathrm{R}_{2} \mathrm{O}$ & II & $\begin{array}{l}\text { embayment empowerment } \\
\text { disillusionment dismem- } \\
\text { berment discouragement } \\
\text { disbarment disbursement } \\
\text { enserfment entrancement } \\
\text { enticement } \\
\text { encystment }\end{array}$ & $\begin{array}{l}\text { bay } \\
\text { power } \\
\text { illusion } \\
\text { member } \\
\text { courage } \\
\text { bar } \\
\text { burse } \\
\text { serf } \\
\text { trance } \\
\text { tice } \\
\text { cyst } \\
\end{array}$ \\
\hline $\begin{array}{l}\text { Adverbial nouns } \\
\mathrm{R}_{2} \mathrm{R}_{3} \mathrm{X}\end{array}$ & $\mathrm{R}_{2} \mathrm{R}_{1} \mathrm{R}_{3} \mathrm{O}$ & II & $\begin{array}{l}\text { enfeeblement ennoblement } \\
\text { enlargement refreshment } \\
\text { revilement refinement }\end{array}$ & \begin{tabular}{|l} 
feeble \\
noble \\
large \\
fresh \\
vile \\
fine
\end{tabular} \\
\hline
\end{tabular}


Table 6.1 shows the main characteristics of the confixed word-formation rows by the category of the derived word. $\mathrm{R}=$ structures are grouped by the nature of the last derivational step. The structure of $R_{2} R_{1} X$ corresponds to a verbal noun, $R_{2} R_{2} X-$ to a nominal noun, $R_{2} R_{3} X-$ to an adverbial noun.

Table 6.1 proves the fact that any structure will comprise a verb either as a morpheme stem or at the first derivational step. While analyzing rows with both verbal and nominal morpheme stem, we came to the conclusion that these rows have two word-formation $\mathrm{R}=$ structures, one of which has the verb at the second derivational step.

Let's consider categories of derivatives conjugated in word-formation rows with the suffix -ment. The conjugacy will be understood as relations of forced connection between the derivational categories of derivatives (Shepel, 2006).

There are some examples of English derivatives implying the usage of the suffix -ment.

Classification of derivatives by number of words

Table 6.2

\begin{tabular}{|l|l|}
\hline \multicolumn{1}{|c|}{ Derivative } & \multicolumn{1}{c|}{ Examples of words } \\
\hline -ish- & $\begin{array}{l}\text { minishment, ravishment, admonishment, abolishment, establishment, } \\
\text { embellishment, astnonishment, furnishment, polishment, refurbish- } \\
\text { ment, replenishment, relinquishment, publishment, impoverishment, } \\
\text { Englishment, bashment, banishment, lavishment, perishment, vanish- } \\
\text { ment, blemishment, burnishment, cherishment, fleshment }\end{array}$ \\
\hline -age- & assuagement, management, enragement, disparagement, engagement \\
\hline -ach- & impeachment, preachment, detachment, attachment \\
\hline -isse-, -ise-, -ize- aggrandizement, amortizement, advertisement, advisement \\
\hline & divertissement, chastisement \\
\hline -ass-, -ess-, -ase- & $\begin{array}{l}\text { assessment, amassment, harassment, embarrassment, passement, } \\
\text { basement, easement, incasement, abasement, erasement }\end{array}$ \\
\hline -ail-, -ain- & $\begin{array}{l}\text { ailment, bailment, assailment, obtainment, detainment, derailment, } \\
\text { engrailment, retailment, curtailment, entailment }\end{array}$ \\
\hline -oach-, -ouch- & encroachment, avouchment, debouchment \\
\hline -ite- & excitement, inditement, incitement, invitement \\
\hline -ieve-, -ive- & achievement, contrivement, derivement \\
\hline -ave- & pavement, lavement, slavement, enslavement, bereavement \\
\hline -er- & bewilderment, disseverment \\
\hline -ign- & consignment, assignment \\
\hline -uce- & educement, deducement, traducement, introducement, seducement \\
\hline -ace-, -aze- & defacement, effacement, placement, gazement, mazement \\
\hline & \\
\hline
\end{tabular}

Table 6.2 shows that the suffix -ish- is the most productive one as it is added to the suffix -ment most of all, suffixes -ace-, -aze-, -uce-, -ass-, -ess-, -ase-, -ain-, -ail-, -isse-, -ise-, -ize- take the second place. All other derivatives are not numerous by the number of generated words. The structural and semantic aspects of word-formation rows with each derivative will be considered in our further papers. 


\section{Conclusions}

The article provides an overview of the word-formation rows with the suffix -ment according to the main criteria of word-formation rows. The basis of this analysis and review comprises the results of the research we have today.

According to the part of speech of the morpheme, the rows are divided into verbal, nominal and adverbial. Consequently, word-formation rows are paradigmatic, since the motivators are morpheme stems belonging to different parts of speech.

According to homogeneity and heterogeneity, the presented rows are heterogeneous, because there are relators of different parts of speech at the penultimate derivational step. The verbal rows are complex and the nominal and adverbial rows are simple.

Suffixes conjugated with the formant $-m e n t=f l e x$ are considered in the article. In conclusion, one may state that the suffix -ish-comprises the largest group of words with the suffix -ment- presented in the table. The structures and models with each suffix will be described in more details in our future papers. The purpose of our further research is to study word-formation rows with homonymous and polysemous morpheme stems.

\section{References}

Soboleva, P. A. (1980). Slovoobrazovatelnaya polisemiya i omonimiya [Word-formation polysemy and homonymy]. Moscow: Nauka [in Russian].

Shepel, Yu. A. (1989). Modelirovanie slovobrazovatelnyh ryadov polimotivirovannyh prilagatelnyh. Problemy strukturnoj lingvistiki [Modelling of word-formation rows of polymotivated adjectives]. Problems of structural linguistics 1985-1987 (pp.11-27). Moscow: Nauka. [in Russian].

Shepel, Yu. A. (2005). Slovoobrazovatelnyj ryad kak dvustoronnyaya kompleksnaya edinica slovoobrazovatelnogo urovnya [Word-formation row as a two-side complex unit of the word-formation level]. Materials of the III All-Ukrainian Scientific and Practical Conference "Slavonic peoples: history, language, culture" (Vol. 1.), (pp. 34-36). Dnipro: Nauka i osvita [in Russian]. Shepel, Yu. A. (2006). Slovoobrazovatelnyj ryad v sisteme slovoobrazovaniya [Word-formation rows in the word-formation system] Dnepropetrovsk: Nauka i obrazovanie. $304 p$. [in Russian].

Shepel, Yu. A. (2013). Slovoobrazovatelnyj ryad i ego rol v sistemnoj organizacii leksiki. Chast 2: Adektivnye slovoobrazovatelnye ryadya russkogo yazyka [Word-formation row and its role in the systematic organization of vocabulary. Part 2: Adverbial word-formation rows of the Russian language] Dnepropetrovsk: Belaya E. A. 240 p. [in Russian]. 